УДК 633.12:631.524.5

(C) 2011

Тригуб О. В., кандидат сільськогосподарських наук

Устимівська дослідна станція рослинництва

Інституту рослинництва ім. В. Я. Юр'єва НААН України

Ляшенко В. В., кандидат сільськогосподарських наук

Полтавська державна аграрна академія

\title{
ОЦІНКА ПОСУХОСТІЙКОСТІ У РІЗНОМАНІТНИХ ЗА ПОХОДЖЕННЯМ ГЕНОТИПІВ ГРЕЧКИ ЗВИЧАЙНОЇ (Fagopyrum esculentum Moench)
}

Рецензент - доктор сільськогосподарських наук, професор П. В. Писаренко

\begin{abstract}
Наведено результати вивчення набору колекційних зразків протягом 2008-2010 рр. за урожсайними характеристиками та морфологічними показниками в контрастних умовах оточуючого середовища. Як додатковий показник контрастності умов вирочування застосовувався гідротермічний коефіиієнт (ГТК). Встановлено ступінь толерантності до дї екстремальних умов різних характеристик рослинного організму. Серед групи вивчення виділено генотипи з кращзою здатністю до адаптаиії за досить посушливих умов, які є иінним вихідним матеріалом для створення високопродуктивних сортів зі значним потениіалом стійкості до посухи.
\end{abstract}

Ключові слова: гречка, посухостійкість, терморезистентність, урожайність, продуктивність, висота рослини, кількість суцвіть на рослині, маса 1000 зерен.

Постановка проблеми. Гречка - одна 3 найбільш цінних продовольчих культур, здатних забезпечити рентабельне виробництво в усіх гречкосіючих регіонах нашої держави. Однак, не дивлячись на певні досягнення селекції та підвищення загального рівня землеробства, урожайність їі продовжує залишатися на низькому рівні, й особливо в роки з несприятливими умовами вегетації [2]. Вирішити це завдання можливо шляхом більш широкого залучення до генотипу новостворюваних сортів, матеріалу 3 максимальною здатністю до адаптації в змінних умовах оточуючого середовища, тобто генотипів, здатних продовжувати ефективне функціонування генеративної та вегетативної сфери в більш екстремальних умовах і - як результат в більшій мірі реалізувати свій генетичний потенціал урожайності [1].

Аналіз основних досліджень і публікацій, у яких розпочато розв'язання проблеми. Найбільш вагомими лімітуючими факторами під час вегетації гречки $є$ високі температури та низьке вологозабезпечення в найбільш критичний пері- од розвитку - цвітіння-початок достигання [3]. Вирішити питання уникнення співпадання критичних періодів росту та прояву кліматичних факторів лише завдяки висіванню ранньостиглих або пізньостиглих генотипів неефективне. Проте, по-перше, при висіванні ранньостиглого матеріалу ми свідомо зменшуємо потенціал урожайності, що притаманне такому типу сортів. По-друге, при застосуванні пізньостиглих генотипів ми отримуємо сорти із низьким ступенем дружності достигання та потрапляємо з періодом збирання у дощові погодні умови 3 низькими середньодобовими температурами, що ускладнює підсихання значної зеленої маси пізньостиглого матеріалу. Слід мати на увазі й той факт, що останні два роки (2009-2010) вирізнялися настільки розтягнутим періодом посухи і високих температур, що навіть застосування контрастних за тривалістю періоду вегетації генотипів не гарантує досягнення очікуваного результату.

Тому вся робота зі створення адаптивного сортового матеріалу повинна бути направлена на випробування широкого асортименту вихідного матеріалу і пошук серед нього генотипів, що вирізняються підвищеною посухостійкістю і терморезистентністю.

Метою та завданнями досліджень передбачалося вивчення Національної колекції гречки звичайної (Fagopyrum esculentum Moench) за показниками адаптивності та продуктивності в контрастних умовах оточуючого середовища. Відповідно до поставлених завдань проведено оцінку набору зразків колекції різного екологогеографічного походження та виділено генотипи 3 підвищеними показниками посухостійкості й терморезистентності.

Матеріали та методи досліджень. Об'єкт дослідження - 61 зразок: із України - 28, Республіки Білорусь - 6, Російської Федерації - 17, два із Японії, по одному із Грузії, Литви, Кореї та 
Франції. За стандарт використано сорт Українка.

Дослідження з визначення врожайних та адаптивних характеристик досліджуваних зразків гречки проводили протягом 2008-2010 років на полях та в лабораторіях Устимівської дослідної станції рослинництва, розміщеній у центральній частині Лівобережної України, безпосередньо на кордоні між лісостеповою та степовою зонами, в південно-східній частині Полтавської області.

Застосовувався широкорядний спосіб сівби 3 міжряддям 45 см. Кожний сорт висівався по 4 рядки довжиною 3 м, облікова площа ділянки -

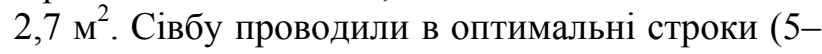
15 травня) 3 нормою висіву 50 насінин на 1 погонний метр. Дослідний матеріал збирали вручну в міру достигання зразків.

Усі спостереження й обліки на дослідних посівах виконані у відповідності до «Методичних вказівок по вивченню колекційних зразків кукурудзи, сорго і круп'яних культур (просо, гречка, рис)» [4] та «Аналізу структури рослин гречки» (Методичні рекомендації) [5], «Методикою державного сортовипробування сільськогосподарських культур. Випуск другий. (Зернові, круп'яні та зернобобові культури)» [6]. Проведено математичну обробку отриманих результатів 3 визначенням середнього значення і $\mathrm{HIP}_{05}$ по сорту та групі вивчення за кожною з ознак [7].

Результати досліджень. Поняття «посуха» включає цілий комплекс метеорологічних умов.
Це довготривалий період без дощів, який супроводжується безперервним падінням відносної вологості повітря та підвищенням температури. Атмосферна й грунтова посухи супроводжують одна одну. Крім того до обтяжливих наслідків призводять суховії [8].

Вирощування набору колекційних зразків упродовж трьох років дало змогу провести повну оцінку різноманітного за походженням матеріалу за стійкістю до абіотичних факторів середовища. Протягом періоду дослідження описувалися дані кількості опадів і середньодобова температура вегетаційного періоду. Як додатковий показник контрастності умов вирощування застосовувався гідротермічний коефіцієнт (ГТК) (табл. 1).

Аналіз даних таблиці 1 вказує на значну нерівномірність розподілу кількості опадів та величини середньої температури по роках. Найбільш близькими до середньобагаторічних були умови 2008 року $-\Gamma T К=1,02$, коли величина температури та кількість опадів були вищими від середньобагаторічних показників. Найбільш екстремальними виявилися умови 2009 року (ГТК=035), коли за високих середньодобових температур спостерігалася недостатня кількість опадів.

Здатність рослини переносити несприятливі умови закладена в генетичній спадковій основі; така здатність може також утворюватися

\section{1. Водно-термічні показники вететаційного періоду гречки за період 2008-2010 років} (дані метеопосту Устимівської ДСР)

\begin{tabular}{|c|c|c|c|c|c|c|}
\hline \multirow{2}{*}{ Роки } & \multirow{2}{*}{ Показники } & \multicolumn{4}{|c|}{ Місяці } & \multirow{2}{*}{ За рік } \\
\hline & & травень & червень & липень & серпень & \\
\hline \multirow{4}{*}{2008} & $\mathrm{t}^{\circ} \mathrm{C}$ повітря & 15,3 & 20,4 & 23,0 & 23,0 & 18,7 \\
\hline & сума $\mathrm{t}^{\circ} \mathrm{C}$ & 474,3 & 633,0 & 713,0 & 713,0 & 2533,3 \\
\hline & сума опадів & 90,5 & 45,0 & 104,5 & 19,0 & 259,0 \\
\hline & ГТК & & & & & 1,02 \\
\hline \multirow{4}{*}{2009} & $\mathrm{t}^{\circ} \mathrm{C}$ повітря & 16,5 & 23,3 & 23,4 & 20,6 & 19,1 \\
\hline & сума $t^{\circ} \mathrm{C}$ & 511,5 & 699,0 & 725,4 & 638,6 & 2574,5 \\
\hline & сума опадів & 54,4 & 27,0 & - & 9,4 & 90,8 \\
\hline & ГТК & & & & & 0,35 \\
\hline \multirow{4}{*}{2010} & $\mathrm{t}^{\circ} \mathrm{C}$ повітря & 18,7 & 23,7 & 25,8 & 26,3 & 21,1 \\
\hline & сума $\mathrm{t}^{\circ} \mathrm{C}$ & 579,7 & 711,0 & 799,8 & 815,3 & 2905,8 \\
\hline & сума опадів & 30,5 & 34,2 & 106,1 & 6,1 & 176,9 \\
\hline & ГТК & & & & & 0,61 \\
\hline \multirow{4}{*}{$\begin{array}{c}\text { Середнє } \\
\text { багаторічне }\end{array}$} & $\mathrm{t}^{\circ} \mathrm{C}$ повітря & 15,9 & 19,5 & 21,0 & 19,8 & 19,1 \\
\hline & сума $t^{\circ} \mathrm{C}$ & 492,9 & 585,0 & 651,0 & 613,8 & 2342,7 \\
\hline & сума опадів & 50,0 & 57,0 & 72,0 & 58,0 & 238,0 \\
\hline & ГТК & & & & & 1,02 \\
\hline
\end{tabular}


організмом, не змінюючи генетичні механізми рослинного організму. В цілому реакція рослин на змінені умови є комплексною, поскільки вміщує зміни як біохімічних, так і фізіологічних процесів [8]. Неабияке значення для селекції має стійкість, яка базується на витривалості клітин рослин, здатності в процесі адаптації перебудовувати як швидкість, так і напрям метаболічних реакцій таким чином, аби у змінених умовах середовища утворювалися необхідні продукти. Вважається, що стійкість визначається всім генотипом, носить полігенний характер і генетично детермінована [9].

У цілому скласти уяву про ступінь посухостійкості зразка можна за зміною урожайних характеристик (маси плодів 3 одиниці площі, продуктивності рослини, крупності плодів) та морфологічних показників (висоти рослини та кількості суцвіть на рослині) в сприятливі й стресові роки вирощування.

Проведений аналіз дав змогу із досліджуваної групи виділити зразки, що вирізняються не лише підвищеною урожайністю (в порівнянні 3 контролем та середнім по групі показником), а й високим рівнем стабільності прояву урожайних характеристик по роках, незалежно від ступеню впливу стрес-фактора (табл. 2).

Зауважимо, що найекстремальнішим за воднотемпературним режимом рік був і найменш урожайним у всіх без винятку зразків, але навіть у посушливих умовах урожайні характеристики більш пристосованого до місцевих умов селекційного матеріалу значно перевищували урожайність місцевих сортів і форм. У той же час у найбільш сприятливий 2008 рік селекційні сорти i форми значно перевищували місцеві як за загальною урожайністю, так і за їі складовими (продуктивністю, кількістю суцвіть на рослині, масою 1000 зерен та ін.). Порівняння урожайних показників у 2009 та 2010 рр. вказує на значно більший вплив на рослину посухи в порівнянні 3 підвищеними температурами. Вплив температурного режиму значно знижується у вранішній та вечірній час, що дає змогу хоч і невеликій кількості квіток, але все ж таки пройти процес запилення. За відсутності дощів тривалий час посуха хоч і наростає поступово, але тримаючись довгий час спричиняє згубнішу дію на рослинний організм. При значній листостебловій масі у гречки спостерігається значне пригнічення цвітіння, в'янення листя та верхівок пагонів. Разом iз тим, навіть у найекстремальніших умовах 2009 року, коли сума опадів за червень, липень і серпень склала лише 36,4 мм, повної загибелі рослин не спостерігалося, й навіть мінімальні опади на початку серпня дозволили сформувати незначний за розміром, але достатній для підтримання зразків урожай.

У результаті вивчення проведено розподіл досліджуваних показників на дві групи за ступенем впливу на них несприятливих факторів середовища. Більш стабільними (незалежно від впливу посухи та високих температур) виявилися характеристики маси 1000 зерен і висоти рослини. Значних змін зазнали урожайні показники - кількість суцвіть на рослині, продуктивність, урожайність плодів.

Серед групи сортозразків гречки було виділено генотипи, які у змінних умовах оточуючого середовища проявили себе високоврожайним i більш стабільним по роках матеріалом. Загальновідомо, що чим більша у рослини норма реакції на стрес, тим більша його здатність до адаптації. Знаковим $є$ той факт, що серед високоадаптивного матеріалу зустрічаються зразки походженням із України, Росії, Білорусі та Японії. Звичайно, в середньому за три роки урожайнішими виявилися селекційні сорти та форми, але для визначення показника посухостійкості важливішим $є$ характеристика зміни рівня врожайності в контрастних умовах. Найбільш адаптивними виявилися зразки: UC0101199, UC0101155, UC0100192, UC0100195, UC0100305, UC0100953, UC0101936, UC0101993, UC0100501, UC0100941 is України, UC0101797 із Республіки Білорусь, UC0101924, UC0100839, UC0100840, UC0100297 та UC0100234 із Російської Федерації та UC0100947 із Японії.

Виділені генотипи 3 кращою здатністю до адаптації за досить посушливих умов є генетичними джерелами стійкості та цінним вихідним матеріалом для створення високопродуктивних сортів зі значним потенціалом стійкості до посухи.

Висновки: 1. Проведення польових і лабораторних досліджень колекційного матеріалу в контрастні за умовами вирощування роки дало можливість 3 групи вивчення виділити сортозразки 3 високим адаптивним потенціалом за посухостійкістю й терморезистентністю.

2. Розподілено показники урожайності та морфологічні ознаки за ступенем толерантності до дії екстремальних умов оточуючого середовища. Найменший вплив посухи та високих температур відзначено на показники маси 1000 зерен і висоти рослини. Найбільш змінними виявилися ознаки продуктивності рослини, урожайності плодів і кількості суцвіть на рослині. 
СІЛЬСЬКЕ ГОСПОДАРСТВО. РОСЛИННИЦТВО

2. Характеристика урожайних та морфологічних показників у кращих посухостійких зразків (2008-2010 рр.)

\begin{tabular}{|c|c|c|c|c|c|c|c|c|c|c|c|c|c|c|c|}
\hline \multirow{3}{*}{$\begin{array}{c}\text { Номер катало- } \\
\text { гу, походження } \\
\text { та назва зразка }\end{array}$} & \multicolumn{15}{|c|}{ Показники } \\
\hline & \multicolumn{3}{|c|}{$\begin{array}{l}\text { урожайність } \\
\text { плодів, г/м² }\end{array}$} & \multicolumn{3}{|c|}{$\begin{array}{c}\text { продуктивність } \\
\text { рослини, г }\end{array}$} & \multicolumn{3}{|c|}{$\begin{array}{c}\text { маса } 1000 \\
\text { плодів, г }\end{array}$} & \multicolumn{3}{|c|}{$\begin{array}{c}\text { висота рослини, } \\
\text { см }\end{array}$} & \multicolumn{3}{|c|}{$\begin{array}{l}\text { кількість суцвіть } \\
\text { на рослині, шт. }\end{array}$} \\
\hline & $\mathrm{x}_{\mathrm{cep}}$ & $\min$ & $\max$ & $\mathrm{x}_{\text {cep }}$ & $\min$ & $\max$ & $\mathrm{X}_{\mathrm{cep}}$ & $\min$ & $\max$ & $\mathrm{X}_{\mathrm{cep}}$ & $\min$ & $\max$ & $\mathrm{X}_{\mathrm{cep}}$ & $\min$ & $\max$ \\
\hline $\begin{array}{l}\text { UC0101199, } \\
\text { Київська обл., } \\
\text { Українка (ст.) }\end{array}$ & 281,0 & 148,9 & 454,0 & 2,24 & 1,22 & 3,89 & 28,7 & 28,0 & 30,2 & 129 & 121 & 134 & 51 & 45 & 56 \\
\hline $\begin{array}{c}\text { UC0101155, } \\
\text { Хмельницька } \\
\text { обл., Космея }\end{array}$ & 236,7 & 196,1 & 321,0 & 1,98 & 1,32 & 2,68 & 24,9 & 24,0 & 26,0 & 139 & 137 & 141 & 56 & 45 & 66 \\
\hline $\begin{array}{c}\text { UC0100192, } \\
\text { Полтавська } \\
\text { обл. }\end{array}$ & 232,9 & 184,5 & 333,0 & 2,04 & 1,75 & 2,98 & 30,1 & 30,0 & 30,2 & 121 & 104 & 132 & 47 & 39 & 54 \\
\hline $\begin{array}{c}\text { UC0100195, } \\
\text { Полтавська } \\
\text { обл. }\end{array}$ & 249,3 & 195,1 & 343,2 & 2,20 & 1,77 & 3,22 & 29,1 & 28,2 & 30,0 & 115 & 106 & 124 & 48 & 36 & 56 \\
\hline $\begin{array}{c}\text { UC0100305, } \\
\text { Полтавська } \\
\text { обл. }\end{array}$ & 260,2 & 192,5 & 342,0 & 2,08 & 1,73 & 2,86 & 24,0 & 22,3 & 26,4 & 122 & 115 & 130 & 51 & 32 & 70 \\
\hline $\begin{array}{c}\text { UC0100953, } \\
\text { Полтавська } \\
\text { обл. }\end{array}$ & 251,2 & 157,7 & 379,1 & 2,25 & 1,73 & 3,56 & 26,9 & 26,0 & 28,8 & 117 & 114 & 121 & 48 & 35 & 54 \\
\hline $\begin{array}{c}\text { UC0101936, } \\
\text { Полтавська } \\
\text { обл., Детермі- } \\
\text { нантна } 8 \\
\end{array}$ & 232,2 & 171,7 & 374,2 & 2,08 & 1,54 & 3,28 & 27,5 & 26,0 & 28,4 & 120 & 95 & 145 & 51 & 45 & 61 \\
\hline $\begin{array}{c}\text { UC0101993, } \\
\text { Сумська обл., } \\
\text { Ярославна }\end{array}$ & 310,3 & 228,9 & 419,0 & 2,49 & 1,60 & 3,64 & 31,0 & 30,1 & 32,4 & 116 & 107 & 128 & 59 & 58 & 61 \\
\hline $\begin{array}{c}\text { UC0100501, } \\
\text { Сумська обл., } \\
\text { Ямпольська } \\
\text { місцева }\end{array}$ & 256,1 & 190,1 & 386,4 & 2,54 & 1,69 & 4,06 & 23,2 & 22,0 & 25,6 & 114 & 107 & 118 & 48 & 29 & 62 \\
\hline $\begin{array}{l}\text { UC0100941, } \\
\text { Одеська обл. }\end{array}$ & 254,2 & 172,5 & 377,1 & 2,22 & 1,49 & 3,37 & 25,3 & 24,3 & 26,5 & 116 & 114 & 121 & 54 & 28 & 76 \\
\hline $\begin{array}{c}\text { UC0101797, } \\
\text { Могилівська } \\
\text { обл. }\end{array}$ & 251,7 & 172,0 & 327,3 & 2,17 & 1,59 & 3,03 & 24,1 & 24,0 & 24,4 & 112 & 100 & 126 & 58 & 47 & 67 \\
\hline $\begin{array}{c}\text { UC0101924, } \\
\text { Архангельська } \\
\text { обл. }\end{array}$ & 232,9 & 154,7 & 335,0 & 1,90 & 1,34 & 2,64 & 23,5 & 22,0 & 24,4 & 112 & 110 & 114 & 64 & 55 & 72 \\
\hline $\begin{array}{l}\text { UC0100839, } \\
\text { Орловська обл. }\end{array}$ & 230,5 & 150,4 & 310,0 & 1,88 & 1,35 & 2,28 & 25,2 & 24,0 & 26,4 & 108 & 106 & 109 & 47 & 25 & 72 \\
\hline $\begin{array}{c}\text { UC0100840, } \\
\text { Орловська обл. }\end{array}$ & 253,3 & 172,1 & 353,5 & 2,01 & 1,53 & 2,73 & 25,1 & 24,1 & 26,2 & 115 & 110 & 120 & 54 & 48 & 60 \\
\hline $\begin{array}{l}\text { UC0100297, } \\
\text { Амурська обл. }\end{array}$ & 261,1 & 167,2 & 325,4 & 2,16 & 1,48 & 3,13 & 26,1 & 26,0 & 26,4 & 137 & 132 & 142 & 50 & 45 & 60 \\
\hline $\begin{array}{l}\text { UC0100234, } \\
\text { Приморський } \\
\text { край, Марія }\end{array}$ & 224,1 & 158,3 & 316,0 & 1,73 & 1,43 & 2,35 & 28,0 & 27,2 & 28,6 & 153 & 138 & 161 & 56 & 42 & 69 \\
\hline $\begin{array}{c}\text { UC0100947, } \\
\text { Японія }\end{array}$ & 181,8 & 166,4 & 217,2 & 1,47 & 0,98 & 1,91 & 28,3 & 28,0 & 29,1 & & & & & & \\
\hline $\begin{array}{c}\text { Середнє по } \\
\text { групі вивчення }\end{array}$ & 209,8 & 69,5 & 519,0 & 1,78 & 0,58 & 4,56 & 26,6 & 22,0 & 39,0 & 129 & 95 & 183 & 59 & 25 & 127 \\
\hline
\end{tabular}


3. Серед групи вивчення виділено генотипи 3 кращою здатністю до адаптації за досить посушливих умов, які $€$ цінним вихідним матеріалом для створення високопродуктивних сортів зі значним потенціалом стійкості до посухи: UC0101199, UC0101155, UC0100192, UC0100195, UC0100305,

\section{БІБЛІОГРАФІЯ}

1. Алєксєєва О. С. Гречка. - К.: Урожай, 1976. $132 \mathrm{c}$.

2. Алексеєва O. С. Генетика, селекція і насінництво гречки. - К.: Вища школа, 2004. - 214 с.

3. Бочкарёва Л. П. Анализ структуры растения гречихи. // Метод. рекоменд. / Под ред. Алексеевой Е. С. и Гончарук А. В. - Черновцы: ЧернЦНТЕI, 1994. $-45 \mathrm{c}$.

4. Доспехов Б. А. Методика полевого опыта. М.: Агропромиздат, 1985. - $351 \mathrm{c}$.

5. Кротов А. С. Гречиха // Методические рекомендации по изучению коллекционных образцов кукурузы, сорго, и крупяных культур. - Л.: Издво ВИР, 1968. - С. 37-44.

6. Махно Ю. А. Оценка засухоустойчивости се-
UC0100953, UC0101936, UC0101993, UC0100501, UC0100941 із України, UC0101797 із Республіки Білорусь, UC0101924, UC0100839, UC0100840, UC0100297 та UC0100234 з Pociï та UC0100947 із Японії.

лекционного материала льна // Зб. наук. пр. Запоріжжя, 2006. - С. 89-193.

7. Методика державного сортовипробування с.-г. культур. Вип. II. (Зернові, круп'яні та зернобобові культури.) / Під ред. В.В. Волкодава. - К.: 2001. - $112 \mathrm{c}$.

8. Сагайдак $C$. О. Оцінка та добір генотипів льону олійного на посухостійкість // Вісник Полтавської ДАА. - 2009. - №1. - С. 134-136.

9. Тараненко Л. К. Особенности адаптивности и продуктивности эколого-географических групп гречихи. // Сб. тр. междунар. конф., посвящённой 30-летию Научно-исследовательского института крупяных культур. - КаменецПодольский: Абетка, 2002. - С. 181-187. 